\title{
REQUIREMENTS FOR THE MATURATION OF HAMSTER OOCYTES FROM PREOVULATORY FOLLICLES
}

\author{
A. A. HAIDRI AND R. B. L. GWATKIN \\ Merck Institute for Therapeutic Research, Rahway, New Jersey 07065, U.S.A.
}

(Received 15th May 1973)

Oocytes explanted from the ovaries of normally cycling mice mature to polarbody formation and the second metaphase stage in the absence of a fixed $\mathrm{N}_{2}$ source. Optimum maturation occurs with a $\mathrm{Po}_{2}$ of $5 \%$ in the gas phase, although a high proportion will do so even under an air atmosphere (Haidri, Miller \& Gwatkin, 1971). By contrast, oocytes of the golden hamster, Mesocricetus auratus, require isoleucine, glutamine, phenylalanine and methionine for maturation. These amino acids have been incorporated in medium GH-1, specifically developed for the culture of the oocytes explanted from the follicles of the cycling hamster (Gwatkin \& Haidri, 1973). Hamster oocytes, have also been found to be extremely sensitive to $\mathrm{O}_{2}$ and rapidly become necrotic under an air-atmosphere (Gwatkin \& Haidri, 1973).

In this communication, we report that golden hamster oocytes explanted from large, preovulatory, follicles require yet additional supplements to support their maturation. A new medium, designated GH-2, has been developed for their cultivation.

Using the methods already described (Gwatkin \& Haidri, 1973) oocytes were collected from 9- to 11-week-old hamsters, either normally cycling (yield ten to fourteen oocytes) or injected 3 days previously with 25 i.u. PMSG (Organon; yield forty to seventy oocytes). After removal of the cumulus oophorus by pipette, the oocytes were washed and cultured in the wells of a Microtest Plate (Cat. No. 3034, Falcon Plastics) for 12 to $16 \mathrm{hr}$ at $37.5^{\circ} \mathrm{C}$ in an atmosphere of $5 \% \mathrm{O}_{2}, 5 \% \mathrm{CO}_{2}$ and $90 \% \mathrm{~N}_{2}$.

Table 1 shows that oocytes collected from the predominantly small follicles of cycling animals formed polar bodies in Medium GH-1, in agreement with our previous results. Those taken from the enlarged follicles of the PMSGtreated animals, however, became necrotic in this medium. Necrosis was not due to atresia, since there was no significant difference $(P>0.2$ by variance ratio) between the mean number of enlarged follicles and the number of tubal eggs ovulated 11 to $17 \mathrm{hr}$ after an injection of HCG. These tubal eggs were normal in appearance and underwent monospermic fertilization in vitro (R. B. L. Gwatkin, unpublished observation). The addition of either crystalline bovine serum albumin (BSA), or fourteen more amino acids (nine essential and five non-essential for mammalian cells in culture; Eagle, Freeman \& Levy, 1958) offset necrosis, but polar bodies did not form unless both BSA and these 
Table 1. Effect of supplementing medium GH-1 with amino acids and macromolecules on the maturation of hamster oocytes from small and large follicles

\begin{tabular}{|c|c|c|}
\hline & \multicolumn{2}{|c|}{$\begin{array}{l}\text { No. of oocytes } \\
\text { which formed polar bodies } \\
\text { (out of ten tested) }\end{array}$} \\
\hline & Exp. 1 & Exp. 2 \\
\hline Small follicles (normally cycling animals) & 9 & 8 \\
\hline 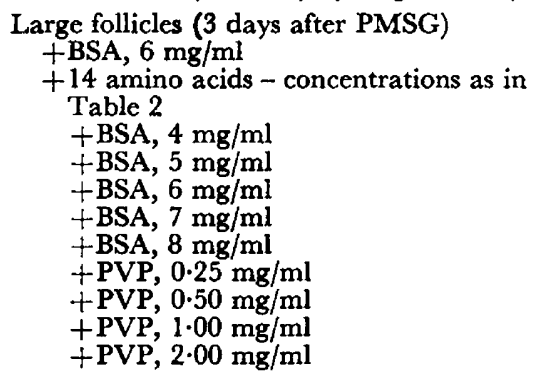 & $\begin{array}{l}\text { Necrosis } \\
0 \\
\\
2 \\
4 \\
8 \\
6 \\
3 \\
0 \\
0 \\
0 \\
0\end{array}$ & $\begin{array}{l}\text { Necrosis } \\
0 \\
\\
4 \\
4 \\
8 \\
6 \\
2 \\
0 \\
0 \\
0 \\
0\end{array}$ \\
\hline
\end{tabular}

BSA-bovine serum albumin; PVP-polyvinyl pyrrolidone.

Table 2. Effect of omitting amino acids one at a time from medium GH-1, supplemented with fourteen additional amino acids and BSA on the maturation of hamster oocytes

\begin{tabular}{l|c|c}
\hline \multicolumn{1}{c|}{ Amino acid omitted } & $\begin{array}{c}\text { Original } \\
\text { concentration } \\
(m \mathrm{M})\end{array}$ & $\begin{array}{c}\text { Mean number of oocytes which } \\
\text { formed polar bodies out } \\
\text { of ten tested in each } \\
\text { experiment } \pm S . E . M .\end{array}$ \\
\hline None & - & $8 \cdot 5 \pm 0 \cdot 6$ \\
Alanine $\dagger$ & $0 \cdot 28$ & $3 \cdot 0 \pm 0 \cdot 4^{* *}$ \\
Arginine & $0 \cdot 30$ & $1 \cdot 5 \pm 0 \cdot 6 * *$ \\
Aspartic acid $\dagger$ & $0 \cdot 20$ & $6 \cdot 8 \pm 0 \cdot 2$ \\
Cystine & $0 \cdot 10$ & $3 \cdot 0 \pm 0 \cdot 4 * *$ \\
Glycine $\dagger$ & $0 \cdot 30$ & $7 \cdot 5 \pm 0 \cdot 3$ \\
Histidine & $0 \cdot 10$ & $3 \cdot 0 \pm 0 \cdot 4^{* *}$ \\
Leucine & $0 \cdot 20$ & $3 \cdot 0 \pm 0 \cdot 4^{* *}$ \\
Lysine & $0 \cdot 20$ & $7 \cdot 5 \pm 0 \cdot 3$ \\
Proline $\dagger$ & $0 \cdot 17$ & $4 \cdot 5 \pm 0 \cdot 3 * *$ \\
Serine $\dagger$ & $0 \cdot 24$ & $2 \cdot 0 \pm 0 \cdot 3 * *$ \\
Threonine & $0 \cdot 20$ & $8 \cdot 0 \pm 0 \cdot 0$ \\
Tryptophane & $0 \cdot 025$ & $8 \cdot 2 \pm 0 \cdot 2$ \\
Tyrosine & $0 \cdot 10$ & $7 \cdot 8 \pm 0 \cdot 6$ \\
Valine & $0 \cdot 20$ & $2 \cdot 2 \pm 0 \cdot 6 *$ \\
All fourteen amino acids omitted & - & $0 \cdot 0$ \\
\hline
\end{tabular}

Essential amino acids added at $\frac{1}{2}$ level in Eagle MEM medium (Eagle, 1959). Non-essential amino acids ( $\dagger$ ) were added at $\frac{1}{2}$ level in 199 medium (Morgan, Morton \& Parker, 1950). The results are means of four experiments, except that for proline which is the mean of six experiments. Those marked ** differ significantly from control $(P<0.00$ l by Student's $t$ test $)$. Other results differ insignificantly $(P>0 \cdot 2)$. 
amino acids were added together. The optimal concentration of BSA was $6 \mathrm{mg} /$ $\mathrm{ml}$. It was not possible to replace BSA by polyvinylpyrrolidone (PVP, Lot No. 901799, Calbiochem. Corp.) at concentrations up to $2 \mathrm{mg} / \mathrm{ml}$.

To establish which of the additional amino acids were required for maturation, oocytes from enlarged follicles were cultured in medium (supplemented with BSA, $6 \mathrm{mg} / \mathrm{ml}$ ) from which one amino acid at a time was omitted. From

Table 3. Composition of medium GH-1 and medium GH-2 for the maturation of hamster oocytes from small and large follicles, respectively

\begin{tabular}{|c|c|c|c|c|}
\hline Component & \multicolumn{2}{|c|}{$\underset{\text { g/litre }}{\text { Medium }} G H-1^{*}$} & \multicolumn{2}{|c|}{ Medium $G H-2$} \\
\hline $\begin{array}{l}\text { Balanced salt solution } \\
\mathrm{NaCl} \\
\mathrm{KCl} \\
\mathrm{CaCl}_{2} \cdot 2 \mathrm{H}_{2} \mathrm{O} \\
\mathrm{NaH}_{2} \mathrm{PO}_{4} \cdot \mathrm{H}_{2} \mathrm{O} \\
\mathrm{MgSO}_{4} \cdot 7 \mathrm{H}_{2} \mathrm{O} \\
\mathrm{NaHCO}_{3} \\
\text { Phenol Red }\end{array}$ & $\begin{array}{l}5 \cdot 47 \\
0 \cdot 40 \\
0 \cdot 10 \\
0 \cdot 14 \\
0 \cdot 25 \\
2 \cdot 00 \\
0 \cdot 01\end{array}$ & $\begin{array}{r}93.7 \\
5.4 \\
0.7 \\
1.0 \\
1.0 \\
24.0 \\
-\end{array}$ & $\begin{array}{l}4 \cdot 93 \\
0 \cdot 36 \\
0 \cdot 10 \\
0 \cdot 14 \\
0 \cdot 25 \\
2 \cdot 00 \\
0.01\end{array}$ & $\begin{array}{r}84.4 \\
4.8 \\
0.7 \\
1.0 \\
1.0 \\
24.0 \\
-\end{array}$ \\
\hline $\begin{array}{l}\text { Energy sources } \\
\text { Na pyruvate } \\
\text { Na lactate } \\
\text { Glucose }\end{array}$ & $\begin{array}{l}0.036 \\
1.53 \\
1.00\end{array}$ & $\begin{array}{r}0 \cdot 3 \\
13 \cdot 6 \\
5 \cdot 5\end{array}$ & $\begin{array}{l}0 \cdot 036 \\
1.53 \\
1.00\end{array}$ & $\begin{array}{r}0 \cdot 3 \\
13 \cdot 6 \\
5 \cdot 5\end{array}$ \\
\hline $\begin{array}{l}\text { Amino acids (all L-isomers) } \\
\text { Alanine } \\
\text { Arginine } \\
\text { Cystine } \\
\text { Glutamine } \\
\text { Histidine } \\
\text { Isoleucine } \\
\text { Leucine } \\
\text { Methionine } \\
\text { Phenylalanine } \\
\text { Proline } \\
\text { Serine } \\
\text { Valine }\end{array}$ & $\begin{array}{c}\overline{-} \\
\overline{0} \\
0.146 \\
0 . \overline{02} 6 \\
\overline{-008} \\
0.016 \\
= \\
=\end{array}$ & $\begin{array}{l}\bar{Z} \\
\overline{1 \cdot 00} \\
\overline{0.20} \\
\overline{0} \\
0 \cdot 05 \\
0 \cdot 10 \\
= \\
=\end{array}$ & $\begin{array}{l}0.025 \\
0.063 \\
0.024 \\
0.146 \\
0.021 \\
0.026 \\
0.026 \\
0.008 \\
0.016 \\
0.020 \\
0.025 \\
0.024\end{array}$ & $\begin{array}{l}0.28 \\
0.30 \\
0 \cdot 10 \\
1 \cdot 00 \\
0 \cdot 10 \\
0 \cdot 20 \\
0 \cdot 20 \\
0 \cdot 05 \\
0 \cdot 10 \\
0 \cdot 17 \\
0 \cdot 24 \\
0 \cdot 20\end{array}$ \\
\hline $\begin{array}{l}\text { Macromolecules } \\
\text { Gryst. bovine } \\
\text { serum albumin (BSA) } \\
\text { Polyvinylpyrrolidone (PVP) }\end{array}$ & $0 . \overline{5}$ & 二 & $6 \cdot 00$ & - \\
\hline $\begin{array}{l}\text { Antibiotics } \\
\text { K Penicillin } \mathrm{G} \\
\text { Streptomycin } \mathrm{SO}_{4}\end{array}$ & $\begin{array}{l}100 \\
100\end{array}$ & & $\begin{array}{l}100 \\
100\end{array}$ & $\begin{array}{l}/ \mathrm{ml} \\
\mathrm{I}\end{array}$ \\
\hline
\end{tabular}

* Gwatkin \& Haidri (1973).

$\dagger 1.9 \mathrm{ml}$ DL-lactic acid $(60 \%$ sodium lactate; Sigma).

the results shown in Table 2, it is apparent that omission of only eight of these amino acids (alanine, arginine, cystine, histidine, leucine, proline, serine and valine) reduced polar body formation appreciably. When a medium was prepared, consisting of GH-1 with these eight amino acids (at the same concentrations as shown in Table 2) and BSA $(6 \mathrm{mg} / \mathrm{ml})$, most of the oocytes extruded polar bodies.

The osmolarity of this medium was varied in duplicate experiments, as described previously (Gwatkin \& Haidri, 1973). No polar-body formation 
occurred at 258 or at 263 mosmol. At 268 mosmol, 90 to $100 \%$ of the oocytes formed polar bodies. Above this value, polar-body formation declined so that, at 278, 288 and 298 mosmol, the percentage of oocytes maturing was 80 to 90 , 70 to 80 and 20 to 30 , respectively.

On the basis of these results, a new medium was developed. It consisted of the components of $\mathrm{GH}-\mathrm{l}$ with a reduced concentration of $\mathrm{NaCl}$ and $\mathrm{KCl}$, supplemented with BSA $(6 \mathrm{mg} / \mathrm{ml})$ and the eight additional amino acids. The medium, designated GH-2 and shown on the right of Table 3, was prepared in essentially the same manner as GH-1 (Gwatkin \& Haidri, 1973). The osmolarity was adjusted to 274 mosmol, since a sharp decline in response was found to occur below 268 mosmol.

In this medium, 90 to $95 \%$ of the preovulatory oocytes formed polar bodies and, when forty of these were stained with aceto-orcein (Donahue, 1968), all were found to have developed second metaphases which were indistinguishable from those of tubal oocytes.

The underlying reason for this change in nutritional requirements as the follicle enlarges is not yet known. However, the cytoplasmic processes of the cumulus cells are withdrawn from the zona pellucida and their tight junctions with the egg surface are broken as ovulation approaches (Baca \& Zamboni, 1967; Zamboni, 1971). A change in the permeability of the vitelline membrane would be expected as a result of these events. Should the oocyte membrane become more permeable, it might be necessary to replace leakage of endogenous substances, such as amino acids, by adding them to the medium. The albumin might be required to supply yet other substances or stabilize the egg membrane.

\section{REFERENCES}

BACA, M. \& ZAMBoni, L. (1967) The fine structure of human follicular oocytes. F. Ultrastruct. Res. 19, 354.

Donahue, R. P. (1968) Maturation of mouse oocyte in vitro. F. exp. Zool. 169, 237.

EAGLE, H. (1959) Amino acid metabolism in mammalian cell culture. Science, N.Y. 130, 432.

Eagle, H., Freeman, A. E. \& Levy, M. (1958) The amino acid requirements of monkey kidney cells in first culture passage. $7 . \exp$. Med. 107, 643 .

Gwatkin, R. B. L. \& HAIDRI, A. A. (1973) Requirements for the maturation of hamster oocytes in vitro. Expl Cell Res. 76, 1.

Haidri, A. A., Miller, I. M. \& Gwatkin, R. B. L. (1971) Culture of mouse oocytes in vitro, using a system without oil or protein. F. Reprod. Fert. 26, 409.

Morgan, J. F., Morton, H. J. \& Parker, R. C. (1950) Nutrition of animal cells in tissue culture. I. Initial studies on a synthetic medium. Proc. Soc. exp. Biol. Med. 73, 1.

Zamboni, L. (1971) Fine morphology of mammalian fertilization, p. 90. Harper \& Row, New York. 